\title{
CONTENTS OF CLINICAL HEMORHEOLOGY, VOLUME 10, NUMBER 1
}

VOLUME 10, NUMBER 1

\section{CONTENTS}

A.L. Copley and S. Witte

A.L. Copley

G. Galea and R.J.L. Davidson

K. De Ceulaer, G.R. Serjeant, R.L. Nagel, H.H. Billett, J. Christakis, D. Loukopoulos, A.J. Bellingham, G.S. Lucas and J. Stuart

D. Laustriat, D. Koutsouris, I. Duwig, S. Goll, G. Mavromatis, O. Kane and M.L. North

J.D. Robertson, R.J. Maughan, K.A. Walker and R.J.L. Davidson

M. Hildesheimer, C. Muchnik and

M. Rubinstein

H.B. Aronson, D. Eimerl and B. Beilin

E. Friederichs, T. Rädisch, H. Winkler and W. Tillmann

V. Annapurna, R.R. Puniyani and R.V. Gupte

C. Janot, S. Muller, F. Streiff, M. Donner and J.F. Stoltz

B.D. Christopher, G.B. Nash, S.A. Steel J.M.F. Pearce and J.A. Dormandy
1 Editorial

Opening Address

3 Fluid Mechanics and Biorheology

Papers

21 Haemorheological changes associated with the menstrual cycle and oral contraceptive therapy

35 Intravenous oxpentifylline and the painful crisis of sickle cell disease

43 Nine days post-thawing red cell conservation in a synthetic medium: Study of erythrocyte deformability

51 Plasma viscosity and the haemodilution following distance running

59 Experimental whole blood hyperviscosity and cochlear action potentials

65 Blood rheology compared in intravenous and halothane anaesthesia

81 Improved solubility of deoxygenated hemoglobin in sickle cell disease: Correlations between erythrocytic $\mathrm{Ca}^{2+}$-ion concentration and hemoglobin solubility

95 Red cell deformability and erythrocyte lipids in hypertension

103 Application of Laser-Doppler electrophoresis to the measurement of blood cell surface charge Brief Communication

113 Filterability of neonatal red cells after normal and complicated pregnancies

119 Abstracts: International Symposium on Biofluid Mechanics and Biorheology, Munich, FRG, 25-28 June 1989

137 Abstracts: 12. Annual Meeting, Japanese Society of Biorheology, Tsukuba Science City, Japan, 5-7 July 1989

145 Abstracts: Symposium on Biorheology, Montreal, Canada, 25 October 1989

149 Announcements

153 A Note

155 Contents of BIORHEOLOGY, Volume 26, Number 5

I Software Survey Section 